\title{
The Purification and Properties of Cellobiose Dehydrogenase from Sclerotium rolfsii and its Role in Cellulolysis
}

\author{
By JAI C. SADANA* AND RAJKUMAR V. PATIL \\ Biochemistry Division, National Chemical Laboratory, Poona 411008, India
}

(Received 22 October 1984; revised 27 February 1985)

An extracellular cellobiose dehydrogenase has been purified from the culture filtrates of Sclerotium rolfsii. The purified enzyme is homogeneous as determined by disc gel electrophoresis, with and without SDS, and by analytical isoelectric focusing in polyacrylamide gel. The enzyme is a single-subunit glycoprotein containing $8.9 \%$ total carbohydrate; its $M_{\mathrm{r}}$ is $63000-64500$, and its isoelectric point $5 \cdot 18$. The enzyme oxidized cellobiose, other cellodextrins and lactose whereas other disaccharides tested were not utilized as substrates. The rate of cellodextrin oxidation decreased and the $K_{\mathrm{m}}$ increased with increasing degree of polymerization of the substrate. Cytochrome $c$ was reduced though at a considerably lower rate than 2,6dichlorophenolindophenol. The natural electron acceptor for the enzyme has not been identified.

\section{INTRODUCTION}

The degradation of cellulose by cellulolytic micro-organisms proceeds through the concerted action of several hydrolytic enzymes (Wood \& McCrae, 1979; Wood et al., 1980), though additional nonhydrolytic, e.g. oxidative (Westermark \& Eriksson, 1974, 1975; Ayers et al., 1978) and phosphorolytic (Sheth \& Alexander, 1967; Alexander, 1961, 1968), enzymes have also been reported to be operative in some cases. In Sporotrichum pulverulentum an oxidative enzyme, cellobiose oxidase, which oxidizes cellobiose and higher cellodextrins to their corresponding aldonic acids using molecular oxygen, has been implicated in cellulose breakdown (Ayers et al., 1978). The enzyme is a haemoprotein and also contains an FAD group. Vaheri $(1982,1983)$ reported that an oxidative system is involved in the degradation of cellulose by Trichoderma reesei, probably at the first stage in the breakdown of crystalline cellulose. Another oxidative enzyme, cellobiose : quinone oxidoreductase, first discovered by Westermark \& Eriksson (1974, 1975 ) in the culture filtrates of Sporotrichum pulverulentum, has been implicated in the breakdown of cellulose and lignin. A similar oxidative enzyme, cellobiose dehydrogenase, but which does not react with quinones, has been found in a non-lignolytic Monilia sp. (Dekker, 1980), and the cellulolytic but non-lignolytic fungus Sporotrichum thermophile (Coudray et al., 1982). The enzyme from both Sporotrichum species oxidizes cellobiose and other cellodextrins (but not cellulose) by a few oxidizing agents but not with molecular oxygen (Westermark \& Eriksson, 1975; Coudray et al., 1982). The cellobiose dehydrogenase from Sporotrichum pulverulentum is a flavoprotein containing FAD as the prosthetic group and produces cellobiono$\delta$-lactone from cellobiose in the presence of lignin degradation products like quinones (Westermark \& Eriksson, 1975).

During the course of purification of various cellulolytic enzymes from the culture filtrates of Sclerotium rolfsii, a cellobiose dehydrogenase was also detected. The enzyme was obtained in a homogeneous state and some of its properties were studied with a view to understanding its possible role in cellulolysis.

Abbreviations: CBDH, cellobiose dehydrogenase; DCPIP, dichlorophenolindophenol. 


\section{METHODS}

Materials. The sources of the materials used have been described previously (Sadana et al., 1983, 1984; Patil \& Sadana, 1984). $p$-Nitrophenyl $\beta$-D-cellobioside was kindly supplied by Dr K. Wakabayashi (Shinshu University, Japan). Cellobiitol, laminaribiose and pustulan were kindly supplied by Dr E. T. Reese (US Army Laboratories, USA); cellodextrins (cellotriose to cellohexaose) were supplied by Dr E. T. Reese and by Professor D. A. I. Goring (Pulp and Paper Institute, Canada). Dichlorophenolindophenol (DCPIP) was from BDH; xylose, arabinose, raffinose, $\mathrm{NAD}^{+}, \mathrm{NADP}^{+}, \mathrm{FMN}, \mathrm{FAD}$, methylene blue, cytochrome $c$ (Candida krusei), p-benzoquinone, ubiquinone Q-10, $\alpha$-tocopherol and menadione were from Sigma. All other chemicals used were from commercial sources and were of analytical grade.

Analytical methods. Reducing sugars, expressed as D-glucose equivalents, were determined by the $p$ hydroxybenzoic acid hydrazide method (Hurst et al., 1977) or the Nelson-Somogyi method (Nelson, 1944; Somogyi, 1952), and D-glucose by the D-glucose oxidase-peroxidase method using 'Glox' reagent (Bergmeyer, 1974). Protein was determined by the Lowry procedure. In column effluents, protein was estimated by measuring the absorbance at $280 \mathrm{~nm}$. The carbohydrate content of the purified enzyme was determined as glucose equivalents by the anthrone-sulphuric acid method (Updegraff, 1969).

Polyacrylamide gel electrophoresis and isoelectric focusing. Analytical disc gel electrophoresis, preparative polyacrylamide gel electrophoresis and isoelectric focusing in polyacrylamide gel were performed as described previously (Shewale \& Sadana, 1981; Patil \& Sadana, 1984). The isoelectric point of the pure enzyme was determined in a $110 \mathrm{ml} \mathrm{LKB}$ electrofocusing column at $5-7^{\circ} \mathrm{C}$ according to the procedure described in the LKB Instruction Manual. Ampholine carrier ampholyte, $\mathrm{pH}$ range 4-6, was used.

The $M_{\mathrm{r}}$ of the enzyme was determined by molecular sieve chromatography (Andrews, 1964) and by gel electrophoresis as described by Hedrick \& Smith (1968). SDS-gel electrophoresis, in gels containing 7.5\% (w/v) total acrylamide monomer and 0.1\% SDS was carried out as described previously (Sadana et al., 1984).

Amino acids (Spackman et al., 1958) and amino sugars (Walborg et al., 1963) were analysed in a Beckman model 120-B automatic amino acid analyser. For amino acids, samples of the enzyme $(0.5-1.0 \mathrm{mg})$ were hydrolysed as described previously (Husain \& Sadana, 1974); for amino sugars, the enzyme was hydrolysed with $4 \mathrm{M}-\mathrm{HCl}$ for $12 \mathrm{~h}$ (Gum \& Brown, 1976). The tryptophan and tyrosine contents were determined by the spectrophotometric method of Goodwin \& Morton (1946).

Enzyme assays. Cellobiose dehydrogenase $(\mathrm{CBDH})$ activity. The assay mixture contained $0.05 \mathrm{ml} 1.8 \mathrm{mM}-\mathrm{DCPIP}$, $0.9 \mathrm{ml} 2.5 \mathrm{~mm}$-cellobiose in $100 \mathrm{~mm}$-phosphate buffer, $\mathrm{pH} 6.3$, and $0.05 \mathrm{ml}$ of suitably diluted enzyme in a glass cuvette at $37^{\circ} \mathrm{C}$ in a Shimadzu spectrophotometer equipped with a thermostatically controlled cuvette holder. The decrease in $A_{600}$ of DCPIP was measured. The reduction of DCPIP caused a slight decrease in the pH of the reaction mixture. The decrease in $A_{600}$ on reduction of DCPIP obtained during the first 5 min of the reaction was used to estimate enzyme activity. (To determine the $\mathrm{pH}$ optimum, reduction of DCPIP was followed at $520 \mathrm{~nm}$ for buffers of $\mathrm{pH}<5$ and at $600 \mathrm{~nm}$ for buffers of $\mathrm{pH}>5$.) The unit of activity (U) is expressed as $\mu$ mol DCPIP reduced $\mathrm{min}^{-1}(\mathrm{ml} \text { enzyme })^{-1}$. The molar absorption coefficient $\left(\varepsilon_{600}\right)$ used for DCPIP was $18.5 \times 10^{3} 1 \mathrm{~mol}^{-1}$ $\mathrm{cm}^{-1}$ at pH 6.5 (Philips \& Langdon, 1962). In experiments using electron acceptors other than DCPIP, the assay procedure was similar (using the various electron acceptors at $1 \mathrm{mg} \mathrm{ml}^{-1}$ ) and the decrease (or increase) in absorbance was determined at their respective absorption maxima (Peel, 1972).

Other assays. $\beta$-Glucosidase, endo- $\beta$-glucanase (carboxymethylcellulase), cellobiohydrolase, and cellulase (Avicel-solubilizing activity) activities were determined as described previously (Sadana et al., 1983, 1984; Patil \& Sadana, 1984; Sadana \& Patil, 1985).

Fungal strain and growth conditions. Sclerotium rolfsii CPC 142 was grown for $14 \mathrm{~d}$ with Cellulose-123 as the sole carbon source as described previously (Shewale \& Sadana, 1978).

\section{RESULTS}

Physical properties of purified enzyme. CBDH from Sclerotium rolfsii was purified as by Patil \& Sadana (1984); the results are summarized in Table 1.

Polyacrylamide gel electrophoresis of the purified enzyme at $\mathrm{pH} 2.9$ and 8.9 , with or without SDS treatment, and isoelectric focusing in $7.5 \%$ polyacrylamide gel over the $\mathrm{pH}$ range $3 \cdot 5-10$, revealed only one protein band (Fig. 1). The $M_{\mathrm{r}}$ for CBDH determined by gel permeation on Bio-Gel P-150 was 63100 as compared to values of 62500 and 64500 obtained by electrophoresis by the slope method and by migration in SDS-polyacrylamide gels, respectively. Carboxyamidomethylation of the reduced form of the enzyme on SDS-gel electrophoresis also gave one protein band with a molecular weight corresponding to the native protein, indicating that the enzyme is composed of a single polypeptide chain. The pI of pure Sclerotium rolfsii CBDH was $5 \cdot 18$. 


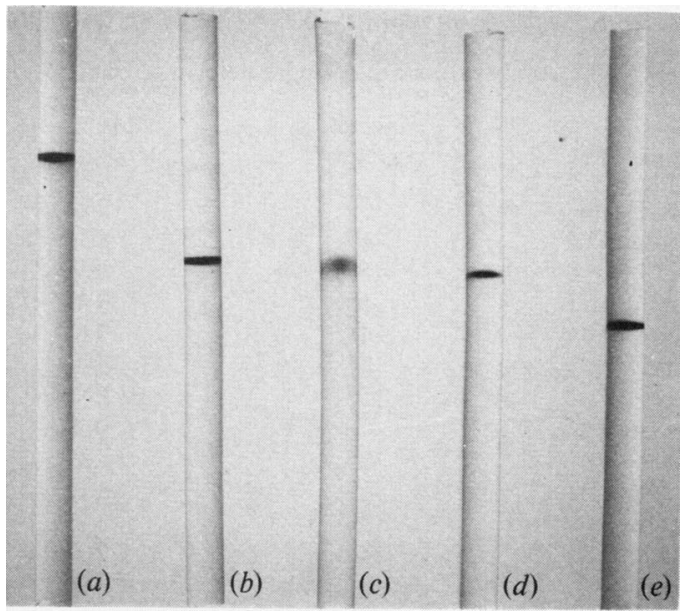

Fig. 1. Polyacrylamide gel electrophoresis and electrofocusing of CBDH from Sclerotium rolfsii. $(a, b)$ Disc gel electrophoresis at $\mathrm{pH} 2.9(a)$ and at $\mathrm{pH} 8.9(b) ;(c)$ SDS-gel electrophoresis (CBDH treated with $1 \%$ SDS containing 1\%2-mercaptoethanol and $0.5 \%$ iodoacetamide $) ;(d)$ the glycoprotein band after disc gel electrophoresis at $\mathrm{pH} 8.9$ stained with periodate fuchsin; (e) isoelectric focusing in $7.5 \%$ polyacrylamide gel in the $\mathrm{pH}$ range $3 \cdot 5-10$.

\section{Table 1. Purification of $C B D H$ from Sclerotium rolfsii}

Starting from the culture filtrate, the purification of $\mathrm{CBDH}$ was done twice. The results obtained were similar; representative results are shown.

\begin{tabular}{|c|c|c|c|c|c|}
\hline $\begin{array}{l}\text { Purification } \\
\text { step }\end{array}$ & $\begin{array}{l}\text { Total } \\
\text { protein } \\
\text { (mg) }\end{array}$ & $\begin{array}{l}\text { Total } \\
\text { activity } \\
\text { (U) }\end{array}$ & $\begin{array}{c}\text { Specific } \\
\text { activity } \\
{\left[\mathrm{U}(\mathrm{mg} \text { protein })^{-1}\right]}\end{array}$ & $\begin{array}{l}\text { Purification } \\
\text { (fold) }\end{array}$ & $\begin{array}{l}\text { Yield } \\
(\%)\end{array}$ \\
\hline & 17202 & 33540 & 1.95 & 1.00 & 100 \\
\hline ulphate, $0-90 \%$ saturation & 13937 & 31820 & $2 \cdot 30$ & $1 \cdot 18$ & 95 \\
\hline 75 chromatography & 7815 & 26570 & $3 \cdot 40$ & 1.74 & 79 \\
\hline $\begin{array}{l}\text { of Fraction A } \\
1-10)\end{array}$ & 6051 & 21180 & $3 \cdot 50$ & 1.79 & 63 \\
\hline dex A-50 chromatography & 50 & 1060 & $21 \cdot 20$ & $10 \cdot 87$ & 3 \\
\hline olyacrylamide gel & $8 \cdot 5$ & 229 & $26 \cdot 90$ & 13.79 & 0.7 \\
\hline
\end{tabular}

Crude extract

Ammonium sulphate, 0-90\% saturation

Sephadex G-75 chromatography

Fraction A

Ultrafiltration of Fraction A

(Amicon PM-10)

DEAE-Sephadex A-50 chromatography

Preparative polyacrylamide gel electrophoresis

Absorption spectrum. The absorption spectrum of the purified CBDH (1 mg protein $\mathrm{ml}^{-1}$ as determined by Lowry method) showed an absorption maximum at $280 \mathrm{~nm}$. The absence of any peak in the regions $445-455 \mathrm{~nm}$ and $405-415 \mathrm{~nm}$ indicated that the enzyme did not contain a flavin or haem component. In contrast, the $\mathrm{CBDH}$ from Sporotrichum pulverulentum is an FADcontaining protein (Westermark \& Eriksson, 1975).

Chemical properties. The CBDH was completely adsorbed on a Concanavalin A-Sepharose column and eluted by $1 \%$ methyl $\alpha$-D-glucopyranoside or methyl $\alpha$-D-mannopyranoside. Polyacrylamide gels stained with Coomassie brilliant blue and with periodate fuchsin (Zacharius et al., 1969) showed a single coinciding band for CBDH (Fig. 1), indicating that $\mathrm{CBDH}$ from Sclerotium rolfsii is a glycoprotein. The total carbohydrate content of the purified enzyme was $8.9 \%$.

CBDH from Sclerotium rolfsii is high in acidic and low in basic amino acid contents (Table 2). Cystine and half-cystine were not detected with or without performic acid oxidation.

Amino sugar analysis of the acid hydrolysate showed that CBDH contains 5.6 residues of glucosamine per molecule of enzyme; galactosamine was not detected. 
Table 2. Amino acid composition of $C B D H$ from Sclerotium rolfsii

The results are from a single determination.

$\begin{array}{lcc}\text { Amino acid } & \begin{array}{c}\text { No. of } \\ \text { residues* }\end{array} & \begin{array}{c}\text { Molar } \\ \text { percentage }\end{array} \\ \text { Aspartic acid } & 59 & 9 \cdot 8 \\ \text { Threonine } \dagger & 49 & 8 \cdot 1 \\ \text { Serine† } & 39 & 6 \cdot 5 \\ \text { Glutamic acid } & 56 & 9 \cdot 3 \\ \text { Proline } & 46 & 7 \cdot 6 \\ \text { Glycine } & 81 & 13 \cdot 4 \\ \text { Alanine } & 53 & 8 \cdot 8 \\ \text { Half-cystine } & 0 & 0 \\ \text { Valine } \$ & 25 & 4 \cdot 1 \\ \text { Methionine\| } & 7 & 1 \cdot 2 \\ \text { Isoleucine } & 30 & 5 \cdot 0 \\ \text { Leucine } § & 44 & 7 \cdot 3 \\ \text { Tyrosine } & 26(24) & 4 \cdot 3 \\ \text { Phenylalanine } & 28 & 4 \cdot 6 \\ \text { Lysine } & 14 & 2 \cdot 3 \\ \text { Histidine } & 7 & 1 \cdot 2 \\ \text { Arginine } & 8 & 1 \cdot 3 \\ \text { Tryptophan } & (30) & 5 \cdot 0 \\ \text { Total residues } & 602 & \end{array}$

\footnotetext{
* Calculated using a molecular weight of 63100 . Values given in parenthesis were determined by the method of Goodwin \& Morton (1946).

$\uparrow$ Extrapolated to zero time.

$\ddagger$ Determined as cysteic acid after performic acid oxidation.

$\$ 72 \mathrm{~h}$ value used.

|| Determined as methionine sulphone after performic acid oxidation.
}

Enzymic properties. The properties of CBDH were tested with cellobiose as electron donor and DCPIP as electron acceptor, unless otherwise indicated. The purified enzyme was stable when stored at $-15^{\circ} \mathrm{C}$ at $\mathrm{pH} 4.5$ and was also stable to repeated freezing and thawing. It was most stable at $\mathrm{pH} 4 \cdot 5-5 \cdot 0$. Heating at $70{ }^{\circ} \mathrm{C}$ for $10 \mathrm{~min}$ destroyed $86 \%$ of the activity; addition of bovine serum albumin $\left(0.5 \mathrm{mg} \mathrm{m}^{-1}\right)$ had no protective effect. The enzyme was completely inactivated by heating at $100^{\circ} \mathrm{C}$ for $2 \mathrm{~min}$.

The $\mathrm{pH}$ and temperature optima were 6.3-6.4 and $37^{\circ} \mathrm{C}$. The $\mathrm{pH}$ optima for CBDH from Monilia sp. (Dekker, 1980) and Sporotrichum pulverulentum (Westermark \& Eriksson, 1975) were between 4.0 and 4.5 . With $0.2 \mu \mathrm{g}$ enzyme, the rate of reduction of DCPIP was linear with time for the first $5 \mathrm{~min}$. Proportionality between activity and enzyme concentration $(0 \cdot 1-0.5 \mu \mathrm{g})$ was also observed in a 2 min assay. The activation energy, calculated from an Arrhenius plot, was $101.9 \mathrm{~J} \mathrm{~mol}^{-1}$. There was no inhibition of CBDH activity at high cellobiose concentrations (25 mM). Glucono-1,5-lactone (100 mM) did not inhibit the activity of CBDH.

Stoichiometry of reaction. Two series of experiments were run, one with cellobiose and one with DCPIP as the limiting substrate. The data obtained showed that one mol DCPIP was reduced per mol cellobiose oxidized.

Specificity and kinetics. (a) With respect to oxidizable substrates. The apparent $K_{\mathrm{m}}$ and $V_{\max }$ values for the oxidation of cellobiose and other cellodextrins by CBDH with DCPIP as electron acceptor are shown in Table 3. The enzyme oxidized cellobiose, other cellodextrins (cellotriose to cellohexaose) and lactose. The relative rate of lactose oxidation compared to that of cellobiose under similar assay conditions was $40 \%$. The turnover rate of $\mathrm{CBDH}$, as represented by $V_{\max }$, for cellobiose, cellotriose, cellotetraose, cellopentaose and cellohexaose decreased, whereas the empirical $K_{\mathrm{m}}$ value increased, with the chain length of the substrate. The higher $K_{\mathrm{m}}$ values for cellodextrins with higher degree of polymerization support the concept of a preferred order of attack based on molecular size of the substrate. No reaction was observed with glucose, sucrose, maltose, xylose, mannose, melibiose, galactose, arabinose, raffinose, fructose, laminaribiose, 
Table 3. Kinetic constants for $C B D H$ from Sclerotium rolfsii

Kinetic studies were carried out in the standard assay system at $37^{\circ} \mathrm{C}, \mathrm{pH} 6 \cdot 3$, varying the substrate concentrations. The $K_{\mathrm{m}}$ and $V_{\max }$ values were calculated from Lineweaver-Burk plots, which were linear in all cases. The results are representative values from two determinations.

$\begin{array}{lcc}\begin{array}{l}K_{\mathrm{m}} \\ (\mu \mathrm{M})\end{array} & \begin{array}{c}V_{\max } \\ \text { Substrate }\end{array} & \\ \begin{array}{l}\text { Electron donor } \\ \text { Cellobiose }\end{array} & 41 \cdot 6 & 36 \cdot 0 \\ \text { Cellotriose } & 62 \cdot 5 & 16 \cdot 6 \\ \text { Cellotetraose } & 66 \cdot 6 & 15 \cdot 4 \\ \text { Cellopentaose } & 83 \cdot 3 & 13 \cdot 3 \\ \text { Cellohexaose } & 100 \cdot 0 & 12 \cdot 5 \\ \text { Electron acceptor } & & \\ \text { DCPIP } & 220 & 36 \cdot 0 \\ \text { Cytochrome } c^{*} & 384 & 0 \cdot 017\end{array}$
* The rate of reduction of cytochrome $c$ was calculated from the molar absorbance at $550 \mathrm{~nm}[\Delta$, reduced minus
oxidized $=18.7 \times 10^{3} 1 \mathrm{~mol}^{-1} \mathrm{~cm}^{-1}$ (Phillips \& Langdon, 1962)].

trehalose, arbutin, cellobiitol, pustulan, lichenan, glucosamine, galactosamine, xylobiose, glucono-1,5-lactone, $p$-nitrophenyl $\beta$-D-glucoside, $p$-nitrophenyl $\beta$-D-cellobioside, carboxymethylcellulose, cellulose and $\mathrm{H}_{3} \mathrm{PO}_{4}$-swollen cellulose.

The apparent $K_{\mathrm{m}}$ values of CBDH at pH $6.5,37^{\circ} \mathrm{C}$, for DCPIP (with cellobiose as electron donor) and cellobiose (with DCPIP as electron acceptor) were $220 \mu \mathrm{M}$ and $41.6 \mu \mathrm{M}$, respectively.

(b) With respect to electron acceptors. Among the artificial electron acceptors tested, DCPIP was the most effective. Cytochrome $c$ and potassium ferricyanide were also reduced, though at a considerably lower rate. With cellobiose as electron donor $(2.5 \mathrm{~mm})$ and at equivalent concentrations of electron acceptors, the rates of cytochrome $c$ and ferricyanide reduction were $30 \%$ and $5 \%$ of that of DCPIP. Methylene blue, (at pH 5.0-6.0), p-benzoquinone, 9,10anthraquinone, ubiquinone Q-10, $\alpha$-tocopherol, menadione, triphenyltetrazolium chloride, phenazine methosulphate, $\mathrm{NAD}^{+}, \mathrm{NADP}^{+}, \mathrm{FMN}, \mathrm{FAD}$ and molecular oxygen failed to accept electrons arising from the enzymic oxidation of cellobiose.

\section{DISCUSSION}

The purified CBDH from Sclerotium rolfsii was obtained in a homogeneous state and was a glycoprotein. The CBDH from Sporotrichum pulverulentum is also a glycoprotein (Westermark \& Eriksson, 1975). The $M_{\mathrm{r}}$ of Sclerotium rolfsii CBDH was 63000-64500; CBDH from Monilia sp. (Dekker, 1980) and Sporotrichum pulverulentum (Westermark \& Eriksson, 1975) had $M_{\mathrm{r}}$ values of 48000 and 58000 , respectively. The $\mathrm{pI}$ of CBDH from Sclerotium rolfsii was $5 \cdot 18$, and that of CBDH from Monilia sp. 5·3-5.5 (Dekker, 1980). The apparent $K_{\mathrm{m}}$ values for Sclerotium rolfsii CBDH (pH 6.3, $37^{\circ} \mathrm{C}$ ) for DCPIP (with cellobiose as electron donor) and cellobiose (with DCPIP as electron acceptor) were $220 \mu \mathrm{M}$ and $41.6 \mu \mathrm{M}$, respectively. The corresponding values for Monilia sp. CBDH (pH 6.6, $37^{\circ} \mathrm{C}$ ) were $80 \mu \mathrm{M}$ and $12 \cdot 2 \mu \mathrm{M}$, respectively (Dekker, 1980). For Sporotrichum thermophile CBDH, the apparent $K_{\mathrm{m}}$ for cellobiose (with DCPIP as oxidant) (pH 7.0, $30^{\circ} \mathrm{C}$ ) was $6.9 \mu \mathrm{M}$ (Coudray et al., 1982).

Like the CBDH from Monilia sp., the Sclerotium rolfsii enzyme does not react with benzoquinones, for which the dehydrogenases from both Sporotrichum pulverulentum and Sporotrichum thermophile have a high affinity. The natural electron acceptor in vivo for CBDH from Sclerotium rolfsii, Monilia sp. and Sporotrichum thermophile has not been indentified. The natural electron acceptor for Sporotrichum pulverulentum CBDH has been identified as phenoxy radicals or quinones emanating from the oxidation of phenols derived as lignin degradation products (Eriksson, 1978).

The concerted action of cellobiohydrolase and endo- $\beta$-glucanases from Sclerotium rolfsii on cellulose produces cello-oligosaccharides, cellobiose and other higher cellodextrins, and small 
quantities of glucose (Sadana \& Patil, 1985). The Sclerotium rolfsii CBDH oxidizes cellobiose and other cellodextrins. The function of CBDH in cellulose hydrolysis could be in the metabolism of cellobiose (and other cellodextrins) by oxidation rather than by intracellular hydrolysis. CBDH (Westermark \& Eriksson, 1975) and cellobiose oxidase (Ayers et al., 1978) have been shown to be a feature of the cellulolytic system of Sporotrichum pulverulentum. The CBDH may have a regulatory role, possibly on the activity of endo- $\beta$-glucanases and cellobiohydrolase, by protecting them from cellobiose inhibition. In most cellulolytic fungi, such a function is usually ascribed to the $\beta$-glucosidase component. In Sporotrichum thermophile, which contained CBDH, $\beta$-glucosidase was totally absent in culture filtrates (see Coudray $e t$ al., 1982), and it was suggested that in this organism the metabolism of cellobiose occurs via oxidation rather than by intracellular hydrolysis. Sclerotium rolfsii, on the other hand, contains both $\beta$-glucosidase (Shewale \& Sadana, 1981; Sadana et al., 1983) and CBDH, both capable of utilizing cellodextrins (cellobiose to cellohexaose); i.e. cellodextrins in Sclerotium rolfsii could be metabolized by oxidation or by intracellular hydrolysis.

The $K_{\mathrm{m}}$ values of Sclerotium rolfsii $\beta$-glucosidase decreased, and the $V_{\max }$ values increased, with the chain length of the cellodextrins (Sadana et al., 1983); the reverse was true for CBDH. With Sclerotium rolfsii BG-III $\beta$-glucosidase at $\mathrm{pH} 4 \cdot 5,37^{\circ} \mathrm{C}$ (optimum conditions for Avicel solubilization: Sadana \& Patil, 1985), the $K_{\mathrm{m}}$ values for cellobiose and cellohexaose were $2 \mathrm{mM}$ and $0.5 \mathrm{mM}$, and those with $\mathrm{CBDH}$ were $45.4 \mu \mathrm{M}$ and $111 \mu \mathrm{M}$, respectively. The turnover numbers [ $\mu \mathrm{mol}$ substrate utilized ( $\mu \mathrm{mol}$ enzyme) ${ }^{-1} \mathrm{~min}^{-1}$ ] of BG-III $\beta$-glucosidase and CBDH for cellobiose and cellohexaose were 2597 and 5035, and 806 and 323, respectively; i.e. even though the $K_{\mathrm{m}}$ values of cellodextrins for CBDH were lower (4.5 to 44 times) than those for $\beta$ glucosidase, the turnover numbers of the pure $\beta$-glucosidase for cellodextrins were much higher ( 3 to 16 times) as compared with $\mathrm{CBDH}$. This suggests that the major route of cellodextrin metabolism in Sclerotium rolfsii is through the hydrolytic pathway via $\beta$-glucosidase.

The absolute $\mathrm{CBDH}$ and $\beta$-glucosidase activities of $S$ clerotium rolfsii culture filtrate under in vivo conditions [pH 3.0,30 $3{ }^{\circ} \mathrm{C}$ (Shewale \& Sadana, 1978) during growth from the 3 rd to the 14 th day] were 0.42 and $1.18 \mu \mathrm{mol}$ cellobiose utilized $\mathrm{min}^{-1} \mathrm{ml}^{-1}$, respectively. Thus, under in vivo conditions, about $30 \%$ of cellobiose could be metabolized via oxidation through CBDH. Under optimum conditions of Avicel solubilization, the absolute CBDH and $\beta$-glucosidase activities were 2.6 and $2.65 \mu \mathrm{mol}$ cellobiose utilized $\mathrm{min}^{-1}\left(\mathrm{ml}\right.$ culture filtrate) ${ }^{-1}$, respectively (Sadana \& Patil, 1985). Although the absolute CBDH and $\beta$-glucosidase activities were about the same, the synergistic effect observed in reconstitution studies with pure cellulolytic enzymes (cellobiohydrolase and endo- $\beta$-glucanases) for solubilization of Avicel was much greater with $\beta$ glucosidases than with CBDH (Sadana \& Patil, 1985). All the data suggested that CBDH has only a minor role in the overall hydrolysis of crystalline cellulose to glucose when Sclerotium rolfsii is grown on cellulose. However, when the organism is growing on lignocellulosic materials, $\mathrm{CBDH}$ may play a more important role in the degradation of both cellulose and lignin, as has been shown for Sporotrichum pulverulentum (Westermark \& Eriksson, 1975), where CBDH has been postulated to be involved in the reduction of lignin degradation products through a reaction coupled with the oxidation of cellobiose.

NCL Communication no. 3651.

\section{REFERENCES}

AleXANDER, J. K. (1961). Characteristics of cellobiose phosphorylase. Journal of Bacteriology 81, 903-910.

Alexander, J. K. (1968). Purification and specificity of cellobiose phosphorylase from Clostridium thermocellum. Journal of Biological Chemistry 243, 28992904.

ANDREws, P. (1964). Estimation of the molecular weights of proteins by Sephadex gel-filtration. Biochemical Journal 91, 222-233.

Ayers, A. R., Ayers, S. B. \& Eriksson, K. E. (1978). Cellobiose oxidase, purification and partial charac- terization of a hemoprotein from Sporotrichum pulverulentum. European Journal of Biochemistry $\mathbf{9 0}$, 171-181.

Bergmeyer, H. U. (1974). Methods of Enzymatic Analysis, vol. 1, pp. 457-458. New York: Academic Press.

Coudray, M. R., Canevascini, G. \& Meier, H. (1982). Characterization of a cellobiose dehydrogenase in the cellulolytic fungus Sporotrichum (Chrysosporium) thermophile. Biochemical Journal 203, 217 284. 
DEKKER, R. F. H. (1980). Induction and characterization of a cellobiose dehydrogenase produced by a species of Monilia. Journal of General Microbiology 120, 309-316.

ERIKSSON, K. E. (1978). Enzyme mechanism involved in cellulose hydrolysis by the rot fungus Sporotrichum pulverulentum. Biotechnology and Bioengineering 20, 317-332.

Goodwin, T. W. \& Morton, R. A. (1946). The spectrophotometric determination of tyrosine and tryptophan in proteins. Biochemical Journal 40, 628640.

GuM, E. K., JR \& Brown, R. D., JR (1976). Structural characterization of a glycoprotein cellulase, 1,4- $\beta$-Dglucan cellobiohydrolase $\mathrm{C}$ from Trichoderma viride. Biochimica et biophysica acta 446, 371-386.

HeDRICK, J. L. \& SMith, A. J. (1968). Size and charge isomer separation and estimation of molecular weights of proteins by disc gel electrophoresis. Archives of Biochemistry and Biophysics 126, 155164.

Hurst, P. L., Nielsen, J., Sullivan, P. A. \& SHEPHERD, M. G. (1977). Purification and properties of a cellulase from Aspergillus niger. Biochemical Journal 165, 33-41.

Husain, M. \& Sadana, J. C. (1974). Nitrite reductase from $A$. fischeri: amino acid composition and hydrodynamic properties. Archives of Biochemistry and Biophysics 163, 21-28.

NELSON, N. (1944). A photometric adaption of the Somogyi method for the determination of glucose. Journal of Biological Chemistry 153, 375-380.

Patil, R. V. \& Sadana, J. C. (1984). The purification and properties of 1,4- $\beta$-D-glucan cellobiohydrolase from Sclerotium rolfsii: substrate specificity and mode of action. Canadian Journal of Biochemistry and Cell Biology 62, 920-926.

PeEL, J. L. (1972). The use of electron acceptors, donors and carriers. Methods in Microbiology 6B, 1-24.

Philips, A. H. \& LANGdon, R. G. (1962). Hepatic triphosphopyridine nucleotide-cytochrome $c$ reductase: isolation, characterization, and kinetic studies. Journal of Biological Chemistry 237, 2652-2660.

Sadana, J. C. \& Patil, R. V. (1985). Synergism between enzymes of Sclerotium rolfsii involved in the solubilization of crystalline cellulose. Carbohydrate Research 139 (in the Press)

Sadana, J. C., Shewale, J. G. \& Patil, R. V. (1983). $\beta$ D-Glucosidases of Sclerotium rolfsii: substrate specificity and mode of action. Carbohydrate Research 118, 205-214.

Sadana, J. C., Lahcke, A. H. \& Patil, R. V. (1984). Endo-1,4- $\beta$-D-glucanases from Sclerotium rolfsii.
Purification, substrate specificity, and mode of action. Carbohydrate Research 133, 297-312.

Sheth, K. \& Alexander, J. K. (1967) Cellodextrin phosphorylase from Clostridum thermocellum. Biochimica et biophysica acta 148, 808-810.

Shewale, J. G. \& Sadana, J. C. (1978). Cellulase and $\beta$-glucosidase production by a basidiomycete species. Canadian Journal of Microbiology 24, 12041216.

Shewale, J. G. \& Sadana, J. C. (1981). Purification, characterization, and properties of $\beta$-glucosidase enzymes from Sclerotium rolfsii. Archives of Biochemistry and Biophysics 207, 185-196.

SoMOGYI, M. (1952). Notes on sugar determination. Journal of Biological Chemistry 195, 19-23.

Spackman, D. H., Stein, W. H. \& Moore, S. (1958). Automatic recording apparatus for use in the chromatography of amino acids. Analytical Chemistry 30, 1190-1206.

UPDEGRAFF, D. M. (1969). Semimicro determination of cellulase in biological materials. Analytical Biochemistry 32, 420-424.

VAHERI, M. P. (1982). Oxidation as a part of degradation of crystalline cellulose by Trichoderma reesei. Journal of Biochemistry 4, 356-363.

VAHERI, M. P. (1983). Formation of oxidative activity for the initial degradation of crystalline cellulose by Trichoderma reesei. Journal of Applied Biochemistry $\mathbf{5}$, 66-74.

WalboRg, E. F., JR, CobB, B. F., III, Adams-mayne, M. \& W ARD, D. N. (1963). Semiautomatic analysis of glucosamine and galactosamine in protein hydrolyzates. Analytical Biochemistry 6, 367-373.

Westermark, U. \& ERIKsson, K. E. (1974). Cellobiose : quinone oxidoreductase, a new wood degrading enzyme from white-rot fungi. Acta chemica scandinavica B28, 209-214.

Westermark, U. \& Eriksson, K. E. (1975). Purification, properties of cellobiose:quinone oxidoreductase from Sporotrichum pulverulentum. Acta chemica scandinavica B29, 419-424.

Wood, T. M. \& McCrae, S. I. (1979). Synergism between enzymes involved in the solubilization of native cellulose. Advances in Chemistry Series no. 181, 181-209.

Wood, T. M., McCrae, S. I. \& Macfarlane, C. C. (1980). The isolation, purification and properties of the cellobiohydrolase component of Penicillium funiculosum cellulase. Biochemical Journal 189, 451-465.

ZaChariUs, R. M., Zell, T. E., Morrison, J. H. \& WOODLOCK, J. J. (1969). Glycoprotein staining following electrophoresis on acrylamide gels. Analytical Biochemistry 30, 148-152. 